\title{
Characterisation of hospital isolates of Moraxella (Branhamella) catarrhalis by SDS-PAGE of whole-cell proteins, immunoblotting and restriction-endonuclease analysis
}

\author{
H. McKENZIE, M. G. MORGAN, J. ZOE JORDENS, M. C. ENRIGHT and MARION BAIN* \\ Department of Medical Microbiology, University Medical Buildings, Foresterhill, Aberdeen AB9 2ZD and \\ - Department of Bacteriology, City Hospital, Greenbank Drive, Edinburgh EH10 5 SB
}

\begin{abstract}
Summary. Sodium dodecyl sulphate-polyacrylamide gel electrophoresis (SDS-PAGE) of whole-cell proteins (WCP), immunoblot analysis and DNA restriction-endonuclease analysis (REA) were applied as potential typing methods to 31 clinically significant strains of Moraxella (Branhamella) catarrhalis, five of which came from a suspected outbreak of nosocomial infection in a respiratory-diseases ward. Twelve of 31 isolates were placed in four groups, each of which containea strains indistinguishable by the three typing techniques used. Each of a further two groups cortained two strains, and they were similar by at least one technique; the remaining 15 strains were unique by all three methods. Four of five strains from the suspected outbreak were indistinguishable by SDS-PAGE of WCP, immunoblotting and REA. Results show that SDS-PAGE of WCP, immunoblotting and REA are suitable techniques for characterising $M$. catarrhalis and that there is a considerable degree of strain heterogeneity. Nosocomial infection with $M$. catarrhalis may be relatively common and further epidemiological studies with a combination of typing techniques are indicated.
\end{abstract}

\section{Introduction}

Moraxella (Branhamella) catarrhalis is now generally accepted as a respiratory pathogen, ranking third in frequency of isolation after Streptococcus pneumoniae and Haemophilus influenzae. It is most commonly involved in acute exacerbations of chronic bronchitis, but is occasionally responsible for pneumonia, ${ }^{1}$ otitis media, ${ }^{2}$ sinusitis ${ }^{3}$ and eye infections. ${ }^{4}$ Nosocomial infection with this organism has previously been suspected, ${ }^{5,6}$ but has been difficult to prove because of the absence of a typing system allowing epidemiological investigation of putative outbreaks.

SDS-PAGE of outer-membrane proteins from 50 different strains of $M$. catarrhalis revealed a high degree of homogeneity ${ }^{7}$ and plasmid analysis was of little value in differentiating strains ${ }^{6,8}$ because plasmids are found infrequently in $M$. catarrhalis. Iso-electric focusing of $\beta$-lactamase enzymes ${ }^{9}$ and bacteriocin typing $^{5}$ have also been investigated and found to be of little value. Sixteen different lipopolysaccharide antigens were described in a study of $302 \mathrm{M}$. catarrhalis strains, but $93 \%$ of isolates fell into only three common antigen types. ${ }^{10}$ However, strains have been

Received 14 March 1991; revised version accepted 11 Sept. 1991. successfully differentiated on the basis of esterase electrophoresis ${ }^{11}$ and a hospital outbreak of $M$. catarrhalis infection has been confirmed by restrictionendonuclease analysis. ${ }^{12}$

We have explored the use of SDS-PAGE analysis of whole-cell proteins (WCP), immunoblotting with pooled normal human serum and DNA restrictionendonuclease analysis (REA) as means of differentiating strains of $M$. catarrhalis. These techniques were applied to 31 clinically significant isolates including five strains from a suspected outbreak of nosocomial infection.

\section{Materials and methods}

\section{Organisms}

Thirty-one clinically significant isolates of $M$. catarrhalis were studied, including five strains from a suspected outbreak of nosocomial infection in a respiratory ward (in Edinburgh) and a further 26 strains selected from routine hospital isolates (in Aberdeen). The only criteria of selection were that isolates were from symptomatic patients and $M$. catarrhalis was the only, or predominant, isolate. In addition, the type strain of $M$. (B.) catarrhalis (NCTC $11020)$ and two non-pathogenic strains of Neisseria ( $N$. pharyngis NCTC 4590 and $N$. lactamica NCTC 


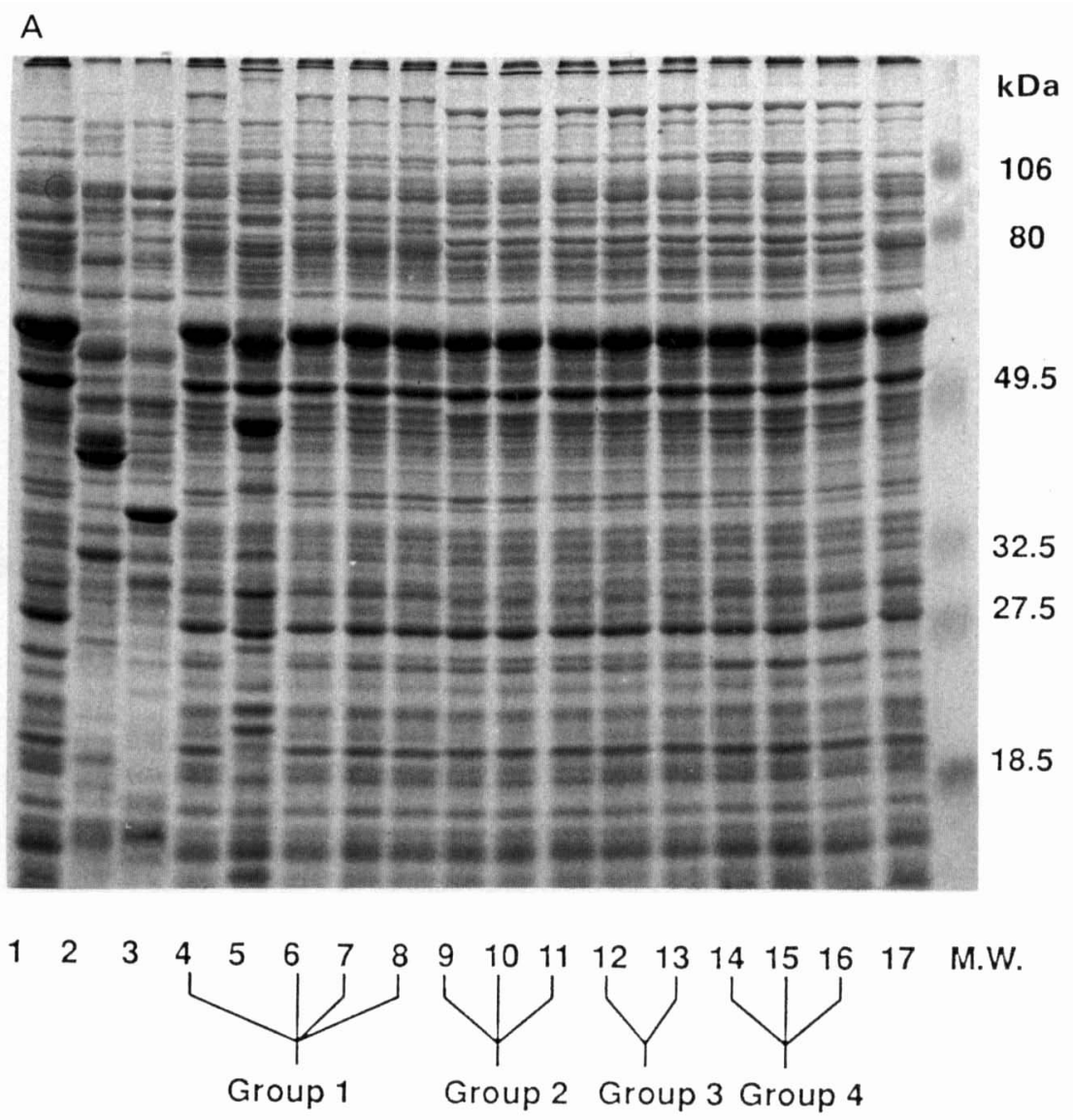

B

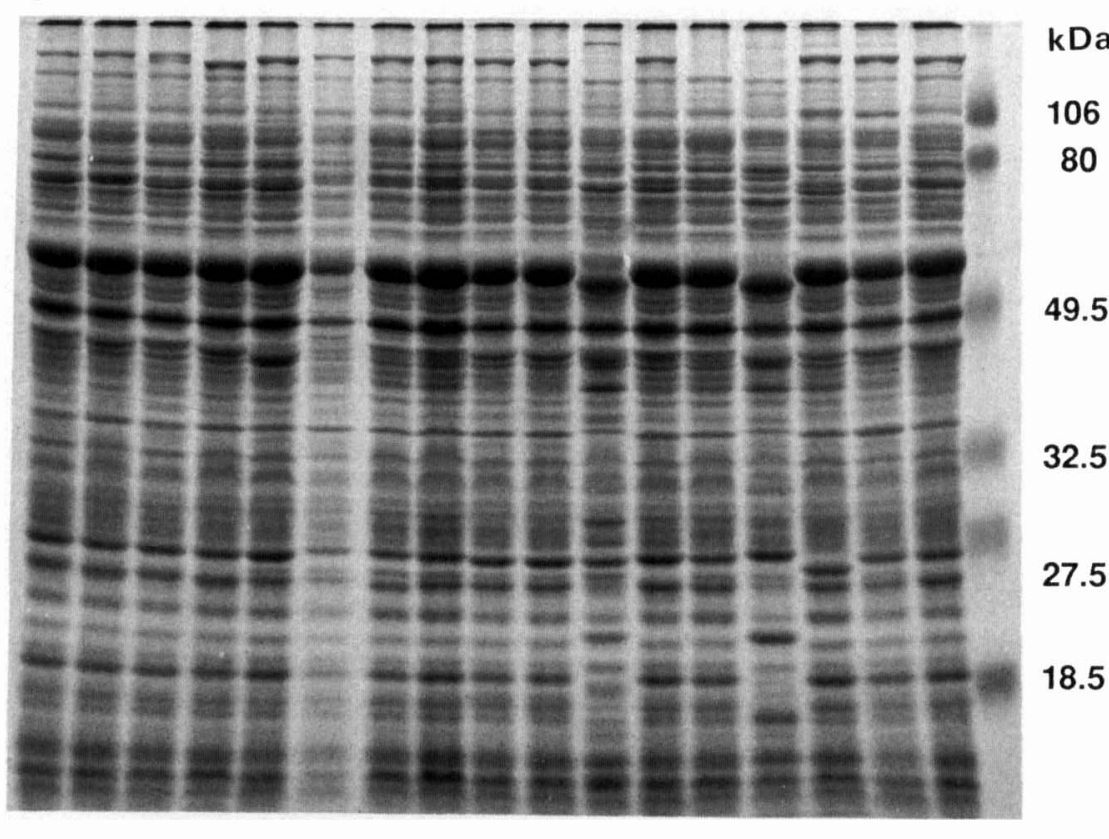

$\begin{array}{llllllllllllllllll}18 & 19 & 20 & 21 & 22 & 23 & 24 & 25 & 26 & 27 & 28 & 29 & 30 & 31 & 32 & 33 & 34 & \text { M.W. }\end{array}$

Fig. 1. SDS-PAGE of WCP of control strains and 31 clinical isolates of $M$. catarrhalis: $M$. catarrhalis strain NCTC 11020 (lane 1); $N$. pharyngis strain NCTC 4590 (2); $N$. lactamica strain NCTC 1061 (3); five strains of $M$. catarrhalis from a suspected nosocomial outbreak of infection in a respiratory-diseases ward (4-8); other clinical isolates of $M$. catarrhalis (9-34). Mol.-wt markers (kDa) are shown to the right of each figure.

1061) were also examined. All $M$. catarrhalis strains gave negative reactions in standard sugar-fermentation tests and positive ones for DNAase production, nitrate reduction and tributyrin hydrolysis.

\section{SDS-PAGE and immunoblotting}

These were performed broadly as described before, ${ }^{13}$ except as detailed below. All strains were cultured on 


\section{A}

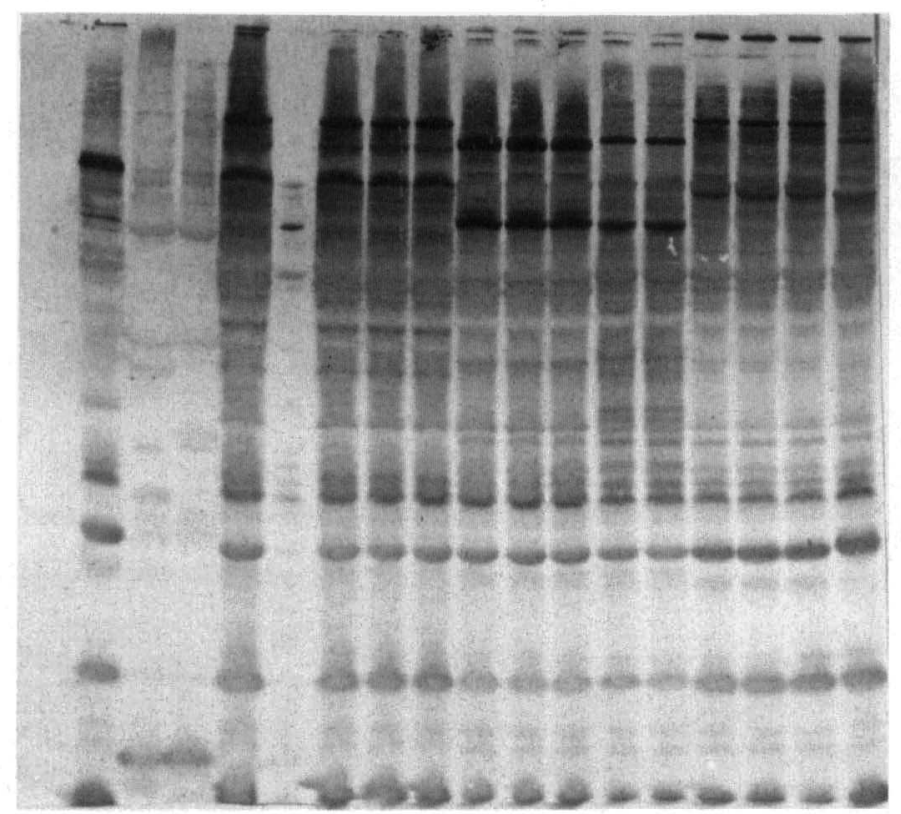

kDa

66.2

45

31

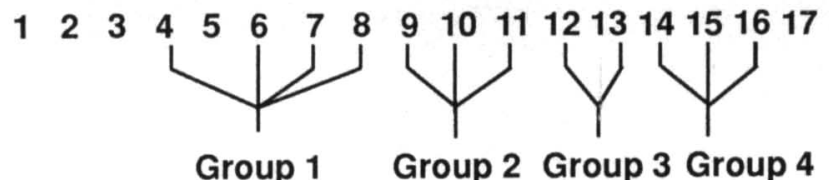

Group 1 Group 2 Group 3 Group 4

B

kDa

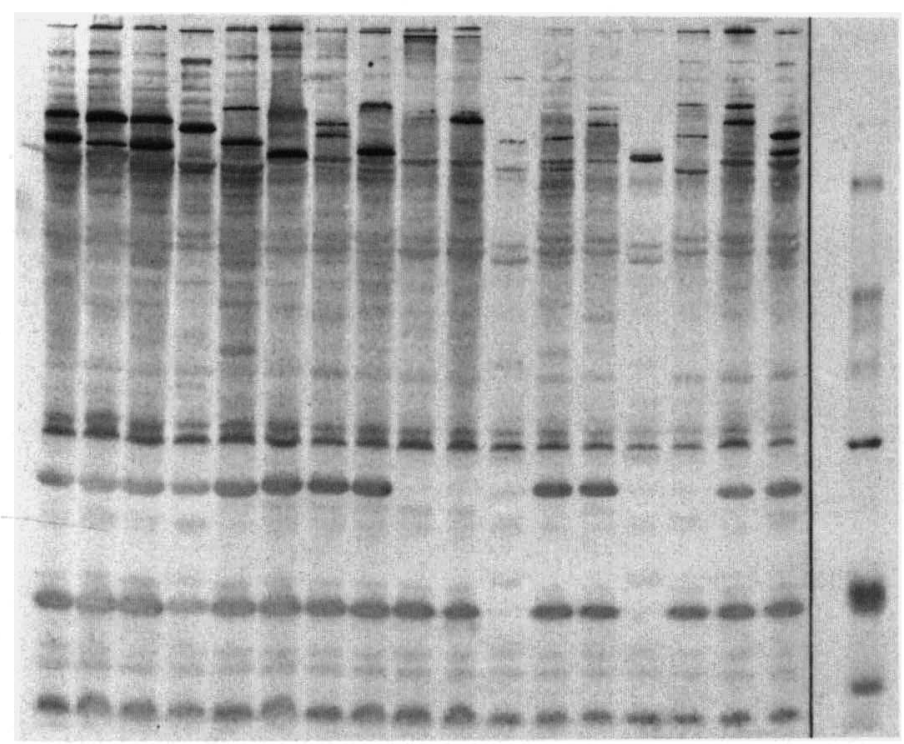

66.2

45

31

21.5

14.4

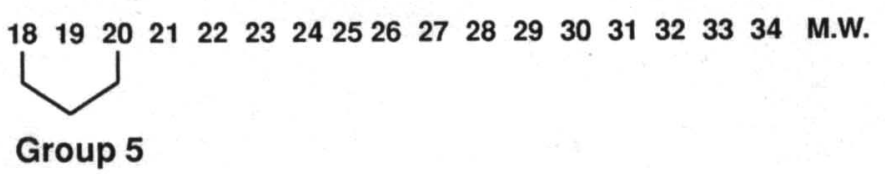

Fig. 2. Immunoblot profiles of organisms described, and in same lane order as, in fig. 1. Mol.-wt markers (kDa) are shown.

blood agar for $24 \mathrm{~h}$ at $37^{\circ} \mathrm{C}$ in $\mathrm{CO}_{2} 5 \%$ in air and harvested, washed and resuspended in sterile saline before sonication. Samples were cooled in an ice bath during sonication for 2 min (Lucas Dawe Ultrasonics Soniprobe). Sonicated extracts were stored at $-70^{\circ} \mathrm{C}$ until use. For SDS-PAGE and immunoblotting, sonicated extracts were mixed with three volumes of $0.01 \mathrm{M}$-Tris-hydrochloride, $\mathrm{pH} \mathrm{6.8}$, containing SDS
$4.4 \% \mathrm{w} / \mathrm{v}$, glycerol $20 \% \mathrm{v} / \mathrm{v}, 2$-mercaptoethanol $20 \%$ $\mathrm{v} / \mathrm{v}$ and bromophenol blue $0.001 \% \mathrm{w} / \mathrm{v}$, and boiled for $5 \mathrm{~min}$ in a water bath. Samples were centrifuged for $5 \mathrm{~min}$ at $13000 \mathrm{rpm}$ in a Micro-centaur centrifuge (MSE) and $30 \mu \mathrm{l}$ of supernate containing $c .1 \mathrm{mg}$ of protein $/ \mathrm{ml}$, as determined by the method of Bradford, ${ }^{\mathbf{1 4}}$ was subjected to electrophoresis on an acrylamide $10 \%$ separating gel with a $4 \%$ stacking 
A
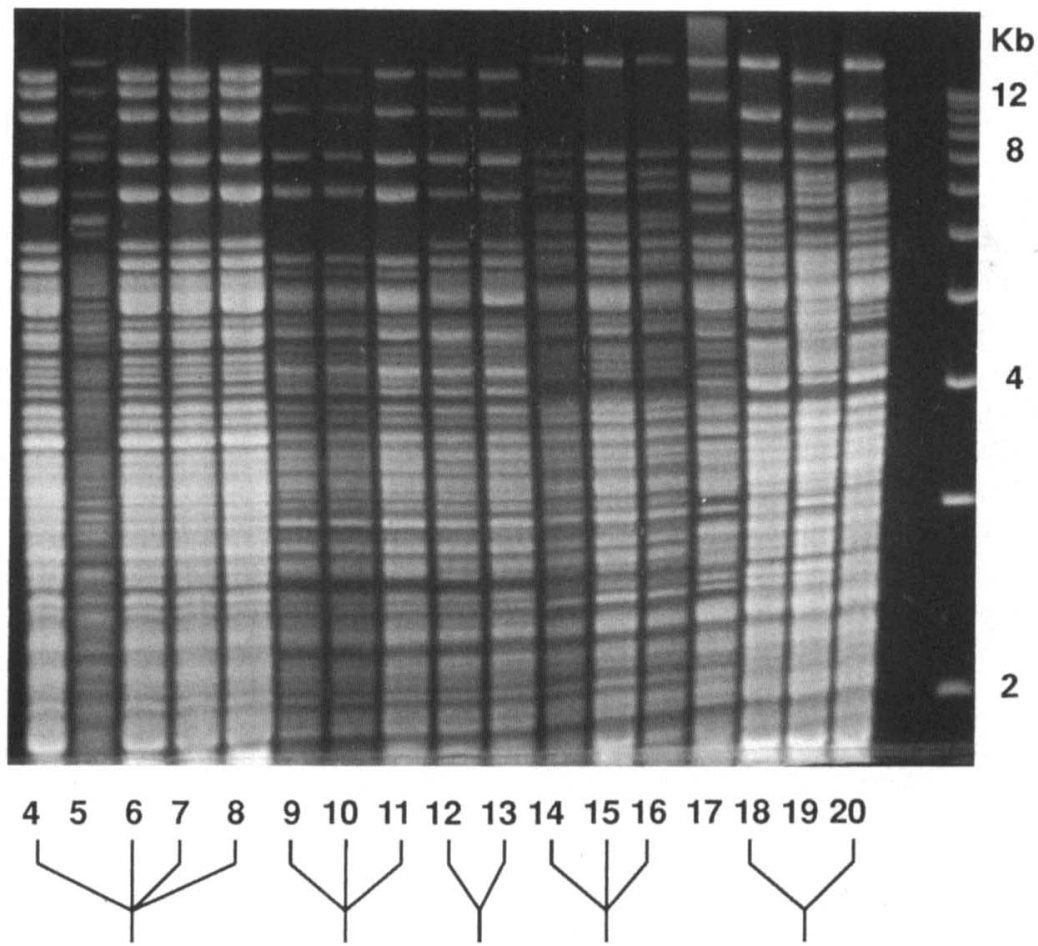

\section{Group 1 \\ Group 2 Group 3 Group 4}

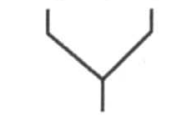

B

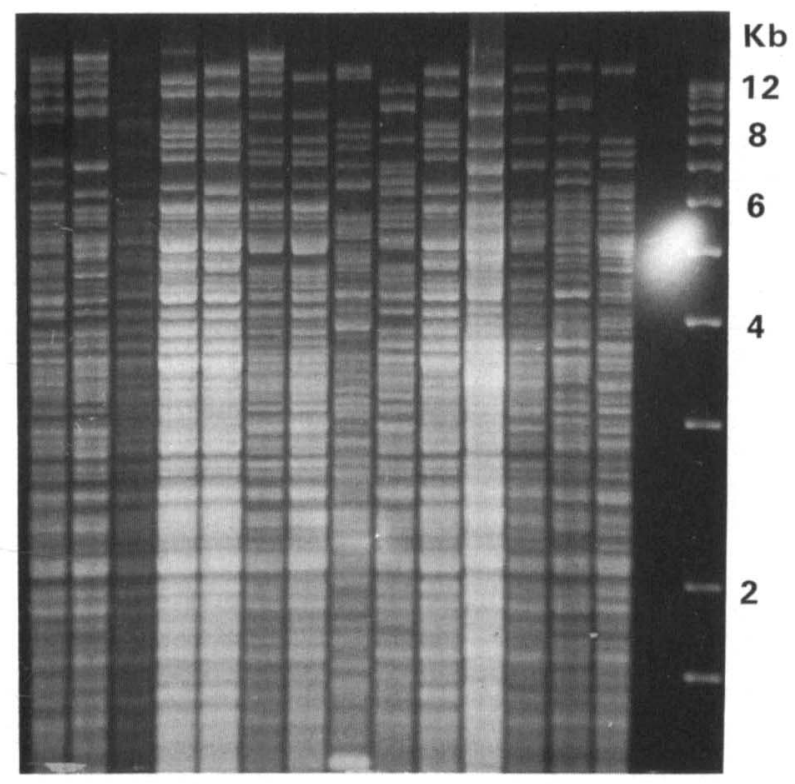

2122232425262728293031323334

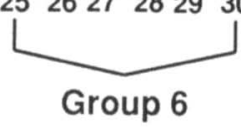

Fig. 3. DNA restriction-endonuclease analysis of 31 clinical isolates of $M$. catarrhalis described, and in same lane order (4-34) as, in figs. 1 and 2.

gel. Electrophoresis was continued until the leading edge of the dye reached the end of the gel and polypeptide bands were stained with Coomassie Brilliant Blue R.

Immunoblotting was performed by overnight electrophoretic transfer of material from acrylamide gels to nitrocellulose membranes (Hybond-C, Amersham, Bucks). Membranes were incubated for $1 \mathrm{~h}$ at $37^{\circ} \mathrm{C}$ in a blocking buffer of $0.1 \mathrm{M}$ phosphate- buffered saline, $\mathrm{pH} 7 \cdot 4$, containing Skimmed-Milk Powder (Oxoid) $3 \% \mathrm{w} / \mathrm{v}$. A single batch of pooled normal human serum (Blood Transfusion Service, Aberdeen Royal Infirmary), diluted 1 in 100 in blocking buffer, was used as the primary antibody and peroxidase-labelled anti-human IgG (SAPU, Law Hospital, Carluke), diluted 1 in 200 in blocking buffer, was used to detect antibody binding. 


\section{DNA extraction and restriction analysis}

Total cellular DNA was extracted by a modification of a method described elsewhere. ${ }^{15}$ Briefly, bacterial colonies from an overnight culture on a blood-agar plate were harvested in $300 \mu \mathrm{l}$ of $50 \mathrm{~mm}$ Tris $(\mathrm{pH} 8)$ with sucrose $25 \%$ in a microfuge tube. Tubes were placed on ice and the following solutions were added: lysozyme $(50 \mathrm{mg} / \mathrm{ml}) 100 \mu \mathrm{l}, 0.2 \mathrm{M}$ EDTA $60 \mu \mathrm{l}$, lysing solution (containing $10 \mathrm{mM}$ EDTA, Triton X-100 2\% $\mathrm{v} / \mathrm{v}$ and $50 \mathrm{~mm}$ Tris, $\mathrm{pH} 8) 300 \mu \mathrm{l}$ and proteinase $\mathrm{K}$ $(5 \mathrm{mg} / \mathrm{ml}) 10 \mu 1$. Resulting suspensions were mixed by inversion, stored on ice for at least $1 \mathrm{~h}$ and extracted once with phenol-chloroform and four times with water-saturated phenol. DNA was precipitated with an equal volume of cold $\left(-20^{\circ} \mathrm{C}\right)$ isopropranol followed by storage at $-20^{\circ} \mathrm{C}$ for $30 \mathrm{~min}$, and collected by centrifugation for $2.5 \mathrm{~min}$. DNA was resuspended in $400 \mu \mathrm{l}$ of $10 \mathrm{~mm}$ Tris (pH 8) with $1 \mathrm{~mm}$ EDTA and $30 \mu \mathrm{l}$ of $5 \mathrm{M} \mathrm{NaCl} ; 5 \mathrm{~mm}$ spermidine $10 \mu \mathrm{l}$ was added and DNA was reprecipitated by storage at $-20^{\circ} \mathrm{C}$ and centrifugation, as before. Final DNA pellets were resuspended in sufficient $10 \mathrm{~mm}$ Tris with $1 \mathrm{~mm}$ EDTA to saturate the DNA $(c .400 \mu l)$ and left at $4^{\circ} \mathrm{C}$ overnight to dissolve.

DNA $(5 \mu \mathrm{g})$ was digested with $c .10$ units of Taq 1 restriction endonuclease in a total volume of $10 \mu \mathrm{l}$ under conditions recommended by the manufacturer (Boehringer Mannheim) and in the presence of RNAase $0.1 \mathrm{mg} / \mathrm{ml}$. The resulting fragments were separated on horizontal agarose $0.8 \%$ gels in $89 \mathrm{~mm}$ Tris, $89 \mathrm{~mm}$ borate, $2 \mathrm{~mm}$ EDTA, pH 8.3. Electrophoresis was terminated when the bromophenol-blue marker reached the end of the gel. Gels were stained with ethidium bromide and photographed under ultraviolet transillumination.

\section{Results}

The WCP profiles of all strains determined by SDSPAGE are shown (fig. 1). The patterns obtained were complex, but clear differences between strains of Neisseria and $M$. (B.) catarrhalis were evident, particularly in relation to the characteristic, heavilystaining bands of $48-60 \mathrm{kDa}$ found in all $M$. catarrhalis strains. Considerable variation among $M$. catarrhalis strains was evident; 23 different WCP patterns were observed among 31 clinical isolates, 19 of which had unique patterns. The remaining 12 strains were classified in four groups, each of indistinguishable WCP pattern, although there were minor differences only among strains of groups 2 and 3 (fig. 1a).

Immunoblotting of the same strains with pooled normal human serum detected a range of $M$. catarrhalis antigens (fig. 2), usually with 1-3 prominent antigenic bands per strain. Major antigens were not detected in strains of $N$. lactamica and $N$. pharyngis (fig. 2a). Comparison of immunoblot patterns confirmed the four SDS-PAGE groupings, with clear differences among strains of groups 2 and 3. Immunoblotting also revealed a fifth grouping of two strains which had shown some minor differences in WCP patterns (group 5; lanes 18 and 20, figs. $1 \mathrm{~b}$ and $2 \mathrm{~b}$ ). The remaining 17 strains had unique immunoblot patterns.

DNA-restriction analysis with Taq 1 enzyme was also performed on the 31 clinical isolates of $M$. catarrhalis and the results are shown (fig. 3). Comparison of REA patterns confirmed the five groupings previously obtained from SDS-PAGE and immunoblotting for 14 strains, but also showed similar patterns of restriction fragments for two strains (group 6 ; lanes 25 and 30 ; fig. 3 b) which were not identical by SDS-PAGE or immunoblotting. Repeat tests on strains in group 6 confirmed that they were indistinguishable by REA but not by other methods. The

Table I. Comparison of results for 31 strains of $M$. catarrhalis examined by SDS-PAGE of WCP, immunoblotting and REA

\begin{tabular}{|c|c|c|c|c|c|c|c|}
\hline Group & $\begin{array}{c}\text { Number } \\
\text { of } \\
\text { isolates }\end{array}$ & $\begin{array}{l}\text { Lane } \\
\text { nos.* }\end{array}$ & Source & $\begin{array}{l}\text { SDS-PAGE } \\
\text { of WCP }\end{array}$ & $\begin{array}{l}\text { immuno- } \\
\text { blotting }\end{array}$ & REA & $\begin{array}{l}\text { Unique by all } \\
\text { methods }\end{array}$ \\
\hline 1 & 4 & $4,6-8$ & $\begin{array}{l}\text { Respiratory ward, } \\
\text { Edinburgh }\end{array}$ & + & + & + & - \\
\hline 2 & 3 & $9-11$ & $\begin{array}{l}\text { Medical unit, } \\
\text { Aberdeen }\end{array}$ & + & + & + & - \\
\hline 3 & 2 & 12,13 & Unrelated wards & + & + & + & - \\
\hline 4 & 3 & $14-16$ & Unrelated wards & + & + & + & - \\
\hline 5 & 2 & 18,20 & $\begin{array}{l}\text { Adjoining paediatric } \\
\text { wards, Aberdeen }\end{array}$ & - & + & + & - \\
\hline
\end{tabular}

* Lane nos., fig. 1. 
Table II. Sources of $M$. catarrhalis strains from a suspected outbreak of nosocomial infection in a respiratory ward in Edinburgh

\begin{tabular}{|c|c|c|c|c|}
\hline \multirow{2}{*}{$\begin{array}{l}\text { Isolate/ } \\
\text { lane no.* }\end{array}$} & \multirow{2}{*}{ Patient } & \multirow{2}{*}{ Disease } & \multicolumn{2}{|c|}{ Date of } \\
\hline & & & admission & isolation \\
\hline 4 & M 69 & COAD & 23 Feb. & $25 \mathrm{Feb}$ \\
\hline 5 & M 47 & Bronchiectasis & $20 \mathrm{Feb}$. & 26 Feb. \\
\hline $\left.\begin{array}{l}6 \\
7\end{array}\right\}$ & M 63 & COAD & 23 Feb. $\}$ & $\begin{array}{l}27 \text { Feb. } \\
2 \text { March }\end{array}$ \\
\hline 8 & M 51 & Asthma & $21 \mathrm{Feb}$. & 3 March \\
\hline
\end{tabular}

COAD, chronic obstructive airways disease.

* Lane nos., see fig. 1.

extent of agreement among the three methods used to characterise the 31 strains is summarised (table I).

Four of five suspected outbreak strains (from Edinburgh) were indistinguishable by SDS-PAGE, immunoblotting and REA (group 1). These strains were isolated from four male patients who were in a respiratory-diseases ward at the same time and for whom clinical details of the origin and date of sampling are shown (table II). $M$. catarrhalis strains were not isolated from other patients on that ward during that period. A further group of three strains was isolated from three different patients in a medical unit in Aberdeen in the absence of previous suspicion of nosocomial infection (group 2). The 15 strains that were found to be unique by all three techniques came from a variety of wards.

\section{Discussion}

Our results confirm previous reports of strain heterogeneity within $M$. catarrhalis. ${ }^{10-12}$ Two of the three techniques used-SDS-PAGE of WCP and immunoblotting - have not previously been applied successfully to the characterisation of $M$. catarrhalis strains. The complexity of WCP profiles obtained makes detailed comparison of strains difficult and immunoblotting produces much simpler patterns which, nevertheless, still have sufficient variability to form the basis of a suitable typing method. The main disadvantage of immunoblotting is its requirement for a source of antibody that is difficult to standardise without batch-to-batch variation. The variety of antigens detected by pooled normal human serum is surprising in view of the apparent homogeneity of outer-membrane proteins reported by other workers. ${ }^{\text {? }}$ Our blotting procedure was designed to detect the most prominent antigens and further work is required

\section{References}

1. Hager H, Verghese A, Alvarez S, Berk SL. Branhamella catarrhalis respiratory infections. Rev Infect Dis 1987; 9: 1140-1149.

2. Marchant CD. Spectrum of disease due to Branhamella catarrhalis in children with particular reference to acute otitis media. Am J Med 1990; 88 Suppl 5A: 15S-19S. to establish their relationship to previously described outer-membrane proteins. However, the present results suggest that serological studies of the immune response to $M$. catarrhalis may give variable results with different strains because of antigenic variation. The absence of demonstrable IgG antibody to $N$. lactamica and $N$. pharyngis strains in normal human serum is consistent with a non-pathogenic role for these organisms.

Previous studies have shown that REA may be a useful technique for characterising strains of $M$. catarrhalis. ${ }^{12,16}$ The enzyme used in the present study produced simple patterns of 5-7 bands in the upper region of the gel allowing easy comparison of different strain patterns. If REA is the only method of typing to be used, it is probably necessary to use more than one enzyme to confirm the groupings obtained. ${ }^{16}$ In the present study, REA in combination with two proteinbased typing techniques, provided confirmation of strain groupings. Thus, for the group-6 strains, despite the identical REA patterns obtained with Taq 1, WCP and immunoblot results suggested that these strains are quite different. However, SDS-PAGE and immunoblotting are susceptible to variable results due to phenotypic change which may account for minor differences in WCP profile between the two group-5 strains that appeared identical by other methods. All three techniques discriminated among strains of $M$. catarrhalis, but no single method was wholly effective and our results confirmed the value of using more than one method for typing. For ease of interpretation, REA and immunoblotting were more acceptable than SDS-PAGE of WCP and the former would form a useful combination for further investigation of the epidemiology of $M$. catarrhalis infection.

Circumstantial evidence that $M$. catarrhalis is an important nosocomial pathogen has been confirmed by REA on only one occasion to date. ${ }^{12} \mathrm{We}$ have demonstrated that three of four patients implicated in a suspected outbreak of infection yielded $M$. catarrhalis strains indistinguishable by the typing methods used. Furthermore, in the absence of any suspicion of nosocomial infection, we have found indistinguishable strains from three different patients in the same medical unit, results suggesting that nosocomial infection with $M$. catarrhalis may be relatively common. More detailed clinical studies based on the typing methods now available are required to assess the epidemiology of this increasingly recognised pathogen.

This study was supported by a grant from the Scottish Home and Health Department. We are grateful to Dr A. F. Maggs for helpful advice and to Mrs A. Innes for technical assistance.
3. Brorson J-E, Axelsson A, Holm SE. Studies on Branhamella catarrhalis (Neisseria catarrhalis) with special reference to maxillary sinusitis. Scand J Infect Dis 1976; 8: 151-155.

4. Romberger JA, Wald ER, Wright PF. Branhamella catarrhalis conjunctivitis South Med J 1987; 80: 926-928.

5. Ahmad F, McLeod DT, Power JT, Calder MA. Branhamella catarrhalis prevalence in a hospital population. $J$ Hosp Infect 1985; 6: 71-74. 
6. Cook PP, Hecht DW, Snydman DR. Nosocomial Branhamella catarrhalis in a paediatric intensive care unit: risk factors for disease. $J$ Hosp Infect 1989; 13: 299-307.

7. Bartos, LC, Murphy TF. Comparison of the outer membrane proteins in 50 strains of Branhamella catarrhalis. J Infect Dis 1988; 158: 761-765.

8. Nicotra B, Rivera M, Luman JI, Wallace RJ. Branhamella catarrhalis as a lower respiratory-tract pathogen in patients with chronic lung disease. Arch Intern Med 1986; 146: 890-893.

9. Nash DR, Wallace RJ, Steingrube VA, Shurin PA. Isoelectric focusing of $\beta$-lactamases from sputum and middle ear isolates of Branhamella catarrhalis recovered in the United States. Drugs 1986; 31 Suppl 3: 48-54.

10. Vaneechoutte M, Verschraegen G, Claeys G, Van den Abeele A-M. Serological typing of Branhemella catarrhalis strains on the basis of lipopolysaccharide antigens. $J$ Clin Microbiol 1990; 28 : 182-187.

11. Picard B, Goullett Ph, Denamur E, Suermondt G. Esterase electrophoresis: a molecular tool for studying the epidemiology of Branhamella catarrhalis nosocomial infection. Epidemiol Infect 1989; 103: 547-554.
12. Patterson TF, Patterson EJ, Masecar BL, Barden GE, Hierholzer WJ, Zervos MJ. A nosocomial outbreak of Branhamella catarrhalis confirmed by restriction endonuclease analysis. J Infect Dis 1988; 157: 996-1001.

13. Maggs AF, Pennington TH. Temporal study of staphylococcal species on the skin of human subjects in isolation and clonal analysis of Staphylococcus capitis by sodium dodecyl sulphate-polyacrylamide gel electrophoresis. $J$ Clin Microbiol 1989; 27: 2627-2632.

14. Bradford MM. A rapid and sensitive method for the quantitation of microgram quantities of protein utilizing the principle of protein-dye binding. Anal Biochem 1976; 72 : 248-254

15. Bjorvatn B, Lund V, Kristiansen B-K, Korsnes L, Spanne O, Lindqvist B. Applications of restriction endonuclease fingerprinting of chromosomal DNA of Neisseria meningitidis. J Clin Microbiol 1984; 19 : 763-765.

16. Patterson JE, Patterson TF, Farrel P, Hierholzer WJ, Zervos MJ. Evaluation of restriction endonuclease analysis as an epidemiologic typing system for Branhamella catarrhalis. $J$ Clin Microbiol 1989; 27: 944-946. 